\title{
Kerjasama Guru Pembimbing dan Badan Narkotika Nasional Kota Pekanbaru dalam Pencegahan Penyalahgunaan Narkoba pada Siswa SMK Negeri 2 Pekanbaru
}

\author{
Rizki Amalia", Tohirin** \\ * Universitas Islam Negeri Sultan Syarif Kasim Riau, Pekanbaru \\ rizki.amalia@gmail.com \\ ** Universitas Islam Negeri Sultan Syarif Kasim Riau, Pekanbaru \\ tohirin@uin-suska.ac.id
}

\section{INFO ARTIKEL}

\section{Riwayat Artikel:}

Diterima: 12 Oktober 2018

Disetujui: 25 Juni 2019

\section{Kata kunci:}

Kerjasama Guru Pembimbing Badan Narkotika Nasional Penyalahgunaan Narkoba

\section{Alamat Korespondensi:}

Tohirin,

Universitas Islam Negeri Sultan Syarif Kasim Riau, Pekanbaru

Email: tohirin@uin-suska.ac.id 


\section{LATAR BELAKANG}

Pendidikan merupakan suatu proses dalam rangka mempengaruhi peserta didik supaya mampu menyesuaikan diri sebaik mungkin dengan lingkungannya, hal tersebut akan menimbulkan perubahan dalam dirinya yang memungkinkan untuk berfungsi memadai dalam kehidupan masyarakat (Hamalik, 2013). Kegiatan pendidikan yang diharapkan dapat mendorong siswa untuk lebih aktif dan lebih bergairah dalam belajar karena kegiatan belajar dan mengajar yang berdaya guna dimaksudkan untuk mencapai tujuan pengajaran atau pembelajaran. Salah satu unsur yang tidak kalah penting dan menjadi keseharusan adalah adanya pelaksanaan bimbingan dan konseling, kegiatan bimbingan dan konseling dapat membantu dan menunjang proses pendidikan, maka di sekolah-sekolah perlu tenaga pembimbing yang paham dan dapat memberikan bantuan kepada siswa dalam menemukan pribadi, mengenal lingkungan dan merencanakan masa depannya.

Guru pembimbing di sekolah bertanggung jawab memberikan bantuan kepada siswa dalam rangka untuk memiliki kesadaran diri mengenai kekhususan yang ada pada dirinya, dapat mengembangkan sikap positif, mampu menghargai orang lain, memiliki rasa tanggung jawab, mengembangkan keterampilan hubungan antar pribadi dan dapat membuat keputusan secara efektif. Selain itu, guru pembimbing juga banyak dihadapkan oleh berbagai permasalahan siswa seperti: tawuran, minum minuman keras, menjadi pencadu narkoba atau NAPZA, kriminalitas, dan pergaulan bebas (free sex), dengan kompleknya masalah siswa disekolah menjadikan guru pembimbing harus menguras tenaga lebih untuk mengatasi masalah siswa. Menurut hasil penelitian dari LPM UI sebagian besar penyalahgunaan narkoba adalah kalangan pelajar dan mahasiswa pada tahun 2011 mencapai 22\% (Suyadi, 2013). Penyalahgunaan narkoba (drugs abuse) adalah suatu pemakaian non medical atau ilegal barang haram yang dinamakan narkoba (narkotik dan obat-obat adiktif) yang dapat merusak kesehatan dan kehidupan yang produktif manusia pemakainya. Manusia pemakai narkoba bisa dari berbagai kalangan, mulai dari level ekonomi tinggi hingga rendah, para penjahat, pekerja, ibu-ibu rumah tangga, bahkan sekarang sudah sampai ke sekolah-sekolah yang jelasjelas terdiri dari para generasi muda, bahkan lebih khusus lagi anak dan remaja (S. Wilis, 2010). Selama ini dunia pendidikan relatif permisif terhadap siswa yang menjadi penyalahgunaan narkoba, sedangkan pihak lain (BNN dan Polisi) justru sangat agresif memberantas penyalahgunaan narkoba. Untuk mencegah agar jangan sampai siswa terlibat dalam penyalahgunaan narkoba maka hendaknya dilakukan usaha-usaha preventif sehingga guru pembimbing melakukan kerjasama dengan pihak lain.

Kerjasama guru pembimbing dengan pihak lain dalam pencegahan penyalahgunaan narkoba di sekolah dapat dilakukan dengan berbagai pihak terkait seperti organisasi kemasyarakatan atau lembaga salah satunya adalah BNNK (Badan Narkotika Nasional Kota) Pekanbaru. BNNK Pekanbaru adalah instansi vertikal Badan Narkotika Nasional yang melaksanakan tugas, fungsi dan wewenang dalam wilayah kota Pekanbaru. Dalam melaksanakan tugas BNNK Pekanbaru meyelenggarakan fungsi pelaksanaan kebijakan operasional Pencegahan dan Pemberantasan Penyalahgunaan dan Peredaran Gelap Narkoba (P4GN) dibidang pencegahan, pemberdayaan masyarakat dan rehabilitasi serta pemberantasan dalam rangka pemetaan jaringan kejahatan terorganisasi penyalahgunaan dan peredaran gelap narkotika, psikotropika, prekusor dan bahan adiktif lainnya kecuali untuk tembakau dan alkohol serta memonitor dan mengendalikan pelaksanaan P4GN wilayah kota Pekanbaru. Guru pembimbing dalam melakukan kerjasama harus jeli dalam memilih permasalahan yang harus dilakukan kerjasama dengan pihak luar yaitu BNNK Pekanbaru. Permasalahan itulah yang menjadi fokus kerja sama karena BNNK Pekanbaru adalah sebuah lembaga yang bergerak dalam bidang anti narkoba yang bertugas secara kuratif sampai yang kepreventif, maka dengan adanya kerjasama guru pembimbing dan pihak BNNK Pekanbaru diharapkan penyalahgunaan narkoba dikalangan siswa dapat dicegah sehingga tidak terjadi hal-hal yang merusak diri siswa. Di Indonesia, perang terhadap narkoba dilakukan di bawah koordinasi sebuah badan bernama Badan Koordinasi Narkoba Nasional. Badan itu terbentuk dengan adanya UU No.22 Tahun 1997 tentang Narkotika. Badan itu dulunya di bawah BAKIN (Badan Koordinasi Intelijen Nasional), sehingga kesulitan mendapat dukungan dana terutama dari dunia internasional. Lembaga ini dibentuk bertepatan dengan dengan Kepres No.116 Tahun 1999 dan baru diresmikan tanggal 1 April 2000. Badan ini termasuk lembaga non-departemen, yang dalam urusannya bertanggung jawab langsung pada presiden, dengan Kapolri sebagai pejabat ex-officio (Joena dkk, 2001).

Semakin baik kerjasama yang dilakukan guru pembimbing dengan BNNK Pekanbaru diharapkan menjadi iklim segar di lingkungan pendidikan, bahwa masalah narkoba sebenarnya atau dapat diatasi dan dicegah melalui kerjasama-kerjasama secara intens baik guru pembimbing berkoordinasi dengan pihak BNNK Pekanbaru di sekolah untuk melakukan sosialisasi atau guru pembimbing mengajak siswa ke kantor BNNK Pekanbaru untuk melakukan diskusi terkait tentang penyalahgunaan narkoba maupun BNNK Pekanbaru memberikan pelatihan kepada guru pembimbing tentang bahaya penyalahgunaan narkoba sehingga nantinya guru pembimbing akan memberikan informasi kepada siswa tentang bahaya penyalagunaan narkoba tersebut, bahkan hubungan itu dapat dilakukan secara lebih yakni BNNK Pekanbaru merekrut pemuda anti penyalahgunaan narkoba dikalangan siswa dengan bantuan guru pembimbing. 
Program pencegahan yang dilakukan pada dasarnya harus mencakup basis sekolah (school based program). Kegiatan ini antara lain untuk menyebarluaskan informasi kepada masyarakat, khususnya yang berada di dalam lingkungan pendidikan. Selain itu juga sebagai pencetus Gerakan Anti Narkoba di semua kalangan siswa dan terjalinnya koordinasi yang erat antara semua unsur yang terlibat dalam mencegah dan menanggulangan penyalahgunaan narkoba. Hal lain yang bisa dilakukan adalah pembentukan Kelompok Teman Sebaya (peer group) anti narkoba. Menurut Visimedia (2006) kegiatan yang dapat diberikan pada remaja diantaranya: 1) pelatihan life skills; 2) mengadakan kegiatan alternatif untuk mengisi luang siswa; 3) membangun kelompok sebaya di sekolah/masyarakat dengan budaya, perilaku yang sehat dan berdisiplin serta bertanggung jawab. Lebih lanjut, Visimedia (2006) mengatakan bahwa Pencegahan Penyalahgunaan Narkoba berbasis Sekolah meliputi: 1) pelaksanaan diklat penanggulangan penyalahgunaan narkoba bagi guru bimbingan konseling (Guru BK); 2) melaksanakan diklat peer counselor tentang permasalahan narkoba bagi siswa di sekolah; 3) melaksanakan penyuluhan klasikal bagi siswa/i di sekolah; 4) melaksanakan outdoor education tentang permasalahan narkoba; 5) melaksanakan penyuluhan bahaya penyalahgunaan narkoba bagi orang tua siswa. Melaksanakan diklat penanggulangan narkoba bagi guru bidang studi tertentu; 6) melaksanakan diklat bagi kepala-kepala sekolah tentang kebijakan penanggulangan permasalahan narkoba di sekolah; dan 7) melaksanakan seminar dan workshop Penanggulangan Permasalahan Narkoba Berbasis Sekolah. Menurut Suyadi (2013) baik guru kelas, guru BK dan pihak lain (Polisi dan BNN) seharusnya secara terpadu mencegah hal-hal yang dapat menimbulkan masalah siswa sebelum masalah tersebut menjadi kasus.

Sekolah Menengah Kejuruan Negeri 2 Pekanbaru yang kemudian penulis singkat SMKN 2 Pekanbaru merupakan salah satu lembaga pendidikan di kota Pekanbaru yang menjadikan program bimbingan dan konseling bagian integral dari proses pendidikan. Di SMKN 2 Pekanbaru keberadaan bimbingan dan konseling telah ada sejak lama dan untuk sekarang ini memiliki guru pembimbing berjumlah empat orang. Guru pembimbing di sekolah ini selain memberikan layanan bimbingan konseling juga melakukan kerjasama baik dari pihak di dalam maupun di luar sekolah, salah satu kerjasama dengan pihak di luar sekolah yaitu dengan BNNK Pekanbaru. Namun, berdasarkan studi pendahuluan yang penulis lakukan penulis menemukan gejala-gejala sebagai berikut; 1) BNNK Pekanbaru yang lebih aktif dengan program pencegahan penyalahgunaan narkoba di sekolah; 2) masih ada guru pembimbing di sekolah yang tidak terlibat dalam kegiatan Penyuluhan BNNK di Sekolah; 3) BNNK Pekanbaru mengadakan pengkaderan anti penyalahgunaan narkoba kepada siswa di sekolah; dan 4) tidak semua guru pembimbing yang melatih siswa pengkaderan anti narkoba untuk membentuk konseling teman sebaya.

Berdasarkan gejala-gejala di atas, maka artikel ini bertujuan untuk mengetahui: (1) wujud kerjasama guru pembimbing dan BNNK Pekanbaru dalam Pencegahan Penyalahgunaan Narkoba dan (2) Faktor-faktor pendukung dan penghambat kerjasama guru pembimbing dan BNNK Pekanbaru dalam pencegahan penyalahgunaan narkoba pada siswa.

\section{METODE}

Artikel ini menggunakan jenis penelitian ini adalah deskriptif kuantitatif yang berlokasi di SMKN 2 Pekanbaru dan BNNK Pekanbaru. Pemilihan lokasi ini didasari atas persoalan-persoalan yang ingin diteliti oleh penulis ada dilokasi ini. Subyek utama penelitian adalah guru pembimbing dan anggota BNNK Pekanbaru bagian pencegahan dan subyek pendukung siswa yang mengikuti pengkaderan di Sekolah Menengah Kejuruan Negeri 2 Pekanbaru. Obyek penelitian ini adalah kerjasama guru pembimbing dan BNNK Pekanbaru dalam pencegahan penyalahgunaan narkoba pada siswa. Populasi penelitian ini adalah guru pembimbing yang berjumlah 4 orang serta siswa yang pernah mengikuti pengkaderan di SMKN 2 Pekanbaru 60 siswa dari 2212 siswa dan anggota BNNK Pekanbaru bagian pencegahan 1 orang. Mengingat populasi di dalam penelitian ini terlalu banyak yakni 60 siswa dan karna siswa pengkaderan kelas XII menghadapi ujian maka penulis mengambil siswa kelas X dan kelas XI dengan menarik sampel sebanyak 50\% dari jumlah siswa tersebut dengan menggunakan teknik purposive sampling, sehingga jumlah sampel sebanyak 30 siswa yang pernah mengikuti pengkaderan dan dari 4 orang guru pembimbing diambil hanya 2 orang guru pembimbing yang pernah melakukan kerjasama dengan BNNK Pekanbaru. Untuk mendapatkan data yang benar dan akurat, penggumpulannya menggunakan teknik sebagai berikut: 1) wawancara, 2) angket, dan 3) dokumentasi. Penelitian ini tergolong kepada penelitian deskritif teknik analisis data yang penulis lakukan adalah deskritif kuantitatif dengan persentase yakni menggambarkan fenomena-fenomena yang ada lalu keduanya diklasifikasikan menjadi dua kelompok yaitu kualitatif dan kuantitatif. Data kualitatif digambarkan dalam bentuk kata-kata kemudian dipisahkan menurut kategorinya untuk memperoleh kesimpulan. Selanjutnya data yang sifatnya kuantitatif dibandingkan dengan jumlah yang diharapkan dan diperoleh persentase (Sudjono, 2004). Hasil pengolahan dikelompokkan dalam beberapa kategori yaitu: 1) apabila persentase berkisar antara $81-100 \%$ ditafsirkan bahwa kerjasama guru pembimbing dan BNNK Pekanbaru dalam pencegahan penyalahgunaan narkoba pada siswa termasuk dalam kategori sangat baik; 2) apabila persentase berkisar antara $61-80 \%$ ditafsirkan bahwa kerjasama guru pembimbing dan BNNK Pekanbaru dalam pencegahan penyalahgunaan narkoba pada siswa termasuk dalam 
kategori baik; 3) apabila persentase berkisar antara 41-60\% ditafsirkan bahwa kerjasama guru pembimbing dan BNNK Pekanbaru dalam pencegahan penyalahgunaan narkoba pada siswa termasuk dalam kategori cukup baik; dan 4) apabila persentase berkisar antara 21-40\% ditafsirkan bahwa kerjasama guru pembimbing dan BNNK Pekanbaru dalam pencegahan penyalahgunaan narkoba pada siswa termasuk dalam kategori tidak baik.

\section{HASIL DAN PEMBAHASAN}

Data dari hasil wawancara dan angket di atas dianalisis untuk menjawab rumusan masalah yang telah diajukan yakni kerjasama guru pembimbing dan BNNK Pekanbaru dalam pencegahan penyalahgunaan narkoba pada siswa.

Wujud Kerjasama Guru Pembimbing dan BNNK Pekanbaru Dalam Pencegahan Penyalahgunaan Narkoba

\section{Pada Siswa}

Temuan penelitian pertama bahwa dalam setiap kegiatan yang dilakukan oleh BNNK di sekolah tetap berhubungan dengan guru pembimbing, karna BNNK beranggapan bahwa tugas guru pembimbing memang untuk membimbing siswa di sekolah dan BNNK membutuhkan bantuan guru pembimbing dalam kegiatan penyuluhan di sekolah. Di SMKN 2 Pekanbaru keterlibatan guru pembimbing ketika BNNK melakukan penyuluhan seperti mempersiapkan siswa yang mengikuti penyuluhan, mempersiapkan tempat dan mendampingi siswa. Temuan peneliti diperkuat dengan pendapat Suyadi (2013) yang mengatakan bimbingan dan konseling adalah kegiatan rutin sekolah yang diselenggarakan secara tatap muka antara guru BK dengan siswa, program bimbingan konseling harus dikembangkan misalnya penyuluhan narkoba, agar berjalan optimal dan maksimal serta tepat sasaran terutama supaya tidak menjemukan bagi siswa dan citra program bimbingan dan konseling di mata siswa beribawa, tidak ada salahnya sekolah mengundang polisi atau pihak BNN untuk menjadi pembicara atau penyuluh/ narasumbernya.

Temuan penelitian kedua bahwa di SMKN 2 Pekanbaru mempunyai eskul PIK (Pusat Informasi Konseling) yang menjadi pembinanya guru pembimbing, eskul PIK ini suatu wadah kegiatan program PKBR yang dikelola dari, oleh dan untuk remaja guna memberikan pelayanan informasi dan konseling tentang Perencanaan Kehidupan Berkeluarga Bagi Remaja serta kegiatan-kegiatan penunjang lainnya, kegiatan-kegiatan di PIK juga membahas tentang pencegahan penyalahgunaan narkoba dan HIV/AIDS. Di SMKN 2 Pekanbaru siswa yang direkrut dalam kegiatan pengkaderan oleh BNNK di ambil dari siswa PIK ini. Bantuan yang diberikan oleh guru pembimbing dalam kegiatan pengkaderan ini sama dengan penyuluhan, guru pembimbing mempersiapkan siswa, mendampingi siswa, mengurus perizinan, serta aktif dalam kegiatan. Bila kegiatan penyuluhan dilaksanakan dalam 1 hari sedangkan kegiatan pengkaderan di sekolah dilaksanakan dalam 3 hari. Kegiatan pengkaderan ini berkelanjutan, setelah pengkaderan di sekolah, ada kegiatan pemantapan kader yang dilaksanakan di hotel dan outbond di Alam Mayang.

Temuan penelitian ketiga bahwa adanya kegiatan penyuluhan dan pengkaderan BNNK di sekolah yang berkoordinasi dengan guru pembimbing tentunya juga melibatkan guru pembimbing dalam mengkampanyekan anti penyalahgunaan narkoba di sekolah, karna dalam setiap kegiatan BNNK memberikan baju, poster, brosur dan buku yang berhubungan untuk mengkampanyekan anti penyalahgunaan narkoba di sekolah. Temuan peneliti diperkuat dengan pendapat Partodiharjo (2013) bahwa kegiatan preventif salah satunya yaitu kampanye anti penyalahgunaan narkoba yang dapat juga dilakukan melalui spanduk, poster, brosur dan baliho, misi yang disampaikan adalah pesan untuk melawan penyalahgunaan narkoba.

Temuan penelitian kelima bahwa setelah pengkaderan guru pembimbing SMKN 2 Pekanbaru membentuk konseling teman sebaya, hal ini berhubungan dengan eskul PIK karna di eskul tersebut juga membahas tentang penncegahan penyalahgunaan narkoba serta pembinanya adalah guru pembimbing, sehingga memudahkan guru pembimbing untuk membentuk konseling teman sebaya. Sekarang sudah ada beberapa siswa yang memberikan penyuluhan dan mengkampanyekan anti penyalahgunaan narkoba tidak hanya di lingkungan SMKN 2 Pekanbaru saja, tetapi siswa tersebut memberikan penyuluhan ke sekolah-sekolah setingkat SMP. Temuan peneliti diperkuat dengan pendapat Suyadi (2013) mengatakan bahwa dalam perkembangannya siswa-siswa yang telah dilantik menjadi anggota Satgas Anti Narkoba oleh BNN harus dibina secara khusus untuk menjadi penyuluh narkoba di sekolah masing-masing atau minimal mereka bisa menjadi motivator dalam upaya mencegah penyalahgunaan narkoba di lingkungan sekolah atau keluarga masing-masing. Para penyuluh muda anti narkoba ini terlebih dahulu diberi pengetahuan tentang narkoba sehingga bisa memberikan pemahaman kepada orang lain terkait dampak negatif dan pengaruh buruk narkoba. Para penyuluh kalangan siswa itu, selanjutnya diharapkan mampu membentuk jaringan dengan satgas di sekolah lain untuk melakukan pemberantasan narkoba dikalangan pelajar secara luas.

Temuan penelitian keenam bahwa guru pembimbing SMKN 2 Pekanbaru mengoptimalkan fungsi pencegahan dengan adanya kerjasama BNNK, adanya pengkaderan, penyuluhan, seminar tentunya menambah wawasan guru pembimbing sehingga guru pembimbing dapat memberikan layanan informasi, bimbingan kelompok, nasehat dan membentuk konseling teman sebaya. 


\section{Faktor Pendukung dan Penghambat Kerjasama Guru Pembimbing dan BNNK Pekanbaru Dalam Mencegah Penyalahgunaan Narkoba Pada Siswa}

Hasil penelitian terungkap bahwa faktor pendukung dan penghambat kerjasama guru pembimbing dan BNNK Pekanbaru dalam pencegahan penyalahgunaan narkoba pada siswa SMKN 2 Pekanbaru adalah:

Temuan penelitian pertama bahwa SMKN 2 Pekanbaru sangat mendukung kegiatan BNNK di sekolah seperti pemberian izin, tempat, sarana dan memberikan disposisi kepada guru pembimbing untuk membantu kegiatan BNNK di sekolah dan selain kegiatan BNNK tidak hanya di sekolah masih banyak even-even yang dilaksanakan BNNK seperti kesenian, outbond, seminar, pelatihan yang SMKN 2 Pekanbaru aktif mengikuti semua kegiatan tersebut. Temuan penelitian kedua bahwa guru pembimbing SMKN 2 Pekanbaru mempunyai tujuan yang sama dengan BNNK Pekanbaru untuk mencegah penyalahgunaan narkoba di sekolah yaitu tujuannya supaya lingkungan sekolah terbebas dari narkoba dan agar pencegahan narkoba di sekolah lebih maksimal. Hal ini diperkuat tugas seksi pencegahan BNNK Pekanbaru memfokuskan kapada upaya menjadikan siswa/pelajar pendidik menengah dan mahasiswa memiliki pola pikir, sikap dan terampil menolak penyalahgunaan dan peredaran narkoba. Temuan penelitian ketiga bahwa fasilitas dan waktu masih kurang memadai, karna kegiatan penyuluhan/pengkaderan BNNK waktunya masih kurang yaitu 1 hari berbeda dengan pengkaderan yang dilaksanakan dalam 3 hari. Temuan penelitian keempat bahwa sosialisasi/penyuluhan belum maksimal karna waktu sosialisasinya hanya sebentar sehingga belum maksimal. Temuan peneliti diperkuat dengan pendapat Suyadi (2013) mengatakan bahwa penyuluhan/sosialisasi narkoba kurang efektif jika hanya berhenti pada penyuluhan semata, supaya lebih efektif penyuluhan tersebut dilanjutkan pada internalisasi nilai-nilai karakter anti narkoba sehingga menjadi sikap yang tercermin dalam kehidupan sehari-hari siswa.

Data dari angket di atas dianalisis untuk menjawab rumusan masalah yang telah diajukan yakni bagaimana kerjasama guru pembimbing dan BNNK Pekanbaru dalam pencegahan penyalahgunaan narkoba pada siswa. Dari Tabel IV. 23 diketahui bahwa seluruh jumlah alternatif jawaban dari 20 item pernyataan angket adalah 600 . Sedangkan yang memilih pada option "sangat sering" sebanyak 222 kali, option "sering" sebanyak 242 kali, option "kadang-kadang” sebanyak 105 kali, option "jarang” sebanyak 24 kali dan option "tidak pernah” sebanyak 7 kali. Karena skor $81,6 \%$ berada pada rentang $81-100 \%$ seperti pada pernyataan di atas maka dapat ditarik kesimpulan bahwa kerjasama guru pembimbing dan BNNK Pekanbaru dalam pencegahan penyalahgunaan narkoba termasuk dalam kategori "sangat baik".

\section{SIMPULAN DAN SARAN}

\section{Simpulan}

Berdasarkan data peneliti yang dari wawancara dapat disimpulkan bahwa wujud kerjasama guru pembimbing dan BNNK Pekanbaru dalam pencegahan penyalahgunaan narkoba pada siswa lebih kepada koordinasi dalam kegiatan penyuluhan dan pengkaderan di sekolah, guru pembimbing membantu mempersiapkan siswa, tempat dan izin serta mengikuti kegiatan, selain itu guru juga guru pembimbing membentuk koseling teman sebaya dari siswa pengkaderan dengan adanya kerjasama guru pembimbing dan BNNK Pekanbaru, guru pembimbing dapat lebih mengoptimalkan fungsi pencegahan untuk mencegah penyalahgunaan narkoba pada siswa. Dari data pendukung yaitu angket dapat diketahui bahwa kerjasama guru pembimbing dan Badan narkotika Nasional kota Pekanbaru dalam pencegahan penyalahgunaan narkoba pada siswa Sekolah Menengah Kejuruan (SMK) Negeri 2 Pekanbaru tergolong dalam kategori sangat baik. Hal ini dapat dilihat dari hasil persentase yang peneliti ambil ketika melakukan penelitian terhadap siswa Sekolah Menengah Kejuruan (SMK) Negeri 2 Pekanbaru yang pernah mengikuti pengkaderan yakni persentasenya adalah $81,6 \%$ yang terletak pada berada $81-100 \%$ (sangat baik).

Faktor Pendukung dan Penghambat kerjasama guru pembimbing dan Badan Narkotika Nasional Kota (BNNK) Pekanbaru dalam pencegahan penyalahgunaan narkoba pada siswa Sekolah Menengah Kejuruan (SMK) Negeri 2 Pekanbaru. Faktor pendukung: adanya dukungan dari sekolah; dan guru pembimbing mempunyai tujuan yang sama dengan BNNK Pekanbaru untuk mencegah penyalahgunaan narkoba pada siswa. Sedangkan faktor penghambat: fasilitas dan waktu yang kurang memadai; dan sosialisasi pihak BNNK Pekanbaru belum maksimal.

\section{Saran}

Berdasarkan penelitian ini ada beberapa hal yang ingin penulis sampaikan yaitu: 1) hendaknya seluruh guru pembimbing di sekolah terlibat dalam kegiatan penyuluhan dan pengkaderan yang dilakukan oleh BNNK; 2) bagi BNNK, agar dapat menambah kegiatan-kegiatan yang berhubungan dalam pencegahan penyalahgunaan narkoba di sekolah; dan 3) BNNK hendaknya memberikan pengkaderan untuk guru pembimbing tidak hanya pada siswa saja. 
22 Instructional Development Journal (IDJ), Vol. 2, No. 1, Juni 2019, Hal. 17-22

\section{DAFTAR RUJUKAN}

Anas Sudjono, (2004), Pengantar Statistik Pendidikan, Jakarta : Raja Grafindo.

BNN Kota Pekanbaru, (2012), Pencegahan Penyalahgunaan Narkoba, Pekanbaru: BNN Kota Pekanbaru.

Oemar Hamalik, (2013), Kurikulum dan Pengajaran, Jakarta: Bumi Aksara.

Satya Joewana dkk, (2001), Narkoba (Petunjuk Praktis Bagi Keluarga untuk Mencegah Penyalahgunaan Narkoba), Yogyakarta: Media Pressindo.

Subagyo Partodiharjo, (2013), Kenali Narkoba dan Musuhi Penyalahgunaannya, Jakarta: Esensi.

Suharsimi Arikunto, (2011), Penilaian dan Penelitian Bidang Bimbingan dan Konseling, Yogyakarta: Aditya Media.

Suyadi, (2013), Mencegah Bahaya Penyalahgunaan Narkoba Melalui Budaya dan Karakter Bangsa, Yogyakarta: CV.Andi Offset.

Sofyan S. Willis, (2010), Remaja dan Masalahnya (Mengupas Berbagai Bentuk Kenakalan Remaja seperti Narkoba, Free Sex dan Pemecahannya), Bandung: Alfa Beta.

, (2009), Konseling Individual Teori dan Praktek, Bandung: Alfabeta.

Visimedia, (2006), Mencegah Terjerumus Narkoba, Jakarta : Visimedia. 